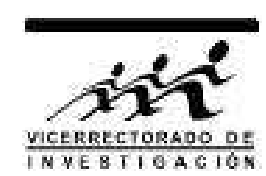

\title{
Variabilidad espacial y temporal de la concentración de clorofila-a en el mar peruano usando imágenes MODIS-AQUA
}

\author{
M. G. Quezada García ${ }^{1}$, R. I. Paredes Peñafiel ${ }^{1}$, F. Carrillo Gomero² y J. Rojas Acuña ${ }^{3 *}$ \\ ${ }^{1}$ Facultad de Ciencias Biológicas, ${ }^{2}$ Facultad de Ingeniería Electrónica y ${ }^{3}$ Facultad de Ciencias Físicas, \\ Universidad Nacional Mayor de San Marcos, Av. Venezuela s/n, Lima 1, Perú
}

Recibido 15 enero 2011 - Aceptado 28 diciembre 2011

\begin{abstract}
La clorofila-a en el mar peruano puede ser medida mediante teledetección en el visible. El objetivo de este trabajo es determinar la concentración de la clorofila-a procedente de las imágenes MODIS sobre el mar peruano. Los mapas de concentración de clorofila-a promedio mensual de enero, febrero, marzo y abril del año 2006 han sido obtenidos del MODIS-AQUA. En cada imagen mensual la concentración de la clorofila-a es mayor cerca a la costa y disminuye gradualmente lejos de la costa. En la costa norte $\left(0-5^{\circ} \mathrm{S}\right)$, la clorofila-a varía entre 0.05 a $0.5 \mathrm{~g} / \mathrm{cm}^{3}$ y se dispersa más alejándose de la costa. En la costa central $\left(5^{\circ}-15^{\circ} \mathrm{S}\right)$ la clorofila-a varía entre 10 a $30 \mathrm{~g} / \mathrm{cm}^{3}$ siendo más denso en la costa y disminuye conforme se aleja de la costa. En la costa sur $\left(15^{\circ}-20^{\circ} \mathrm{S}\right)$ la clorofila-a varía entre 3 a $5 \mathrm{~g} / \mathrm{cm}^{3}$ pero muy cerca a la costa. De enero a abril del 2006 estos valores disminuyeron lentamente por el cambio de estación.
\end{abstract}

Palabras claves: Clorofila a, imágenes por satélite, MODIS, oceanografía.

\section{Spatial and temporal variability of chlorophill a in the Peruvian sea using MODIS- AQUA images}

The chlorophill a in the Peruvian sea must be measured by means of remote sensing in the visible range. The objective of the present work is to determine the chlorophill a concentration using MODIS images from the Peruvian sea. The mean monthly concentration maps of chlorophill a of January, February, March and April of 2006 year has been obtained from the MODIS-AQUA images. In each monthly image the chlrophill a concentration is greater near to coastline and decrese gradually far from the coast. In the Northern coast $\left(0-5^{\circ} \mathrm{S}\right)$, the chlorophill a vary between 0.05 to $0.5 \mathrm{~g} / \mathrm{cm}^{3}$ and it disperse far from the coast. In the Central coast $\left(5^{\circ}-15^{\circ} \mathrm{S}\right)$ the chlorophill a vary between 10 to $30 \mathrm{~g} / \mathrm{cm}^{3}$, it's more dense in the coastline and diminished conform the distance from the coast is increased. In the Southern coast $\left(15^{\circ}-20^{\circ} \mathrm{S}\right)$ the chlorophill a vary between 3 to $5 \mathrm{~g} / \mathrm{cm}^{3}$ very near to the coast. From January to April of 2006 year, these values has been diminished slowly due to the seasonal change.

Keywords: Chlorophill a, satellite images, MODIS, Oceanography.

Nota de los editores. Este es un artículo que ha sido publicado en algunos sítios de internet. Hemos aceptado este artículo en vista del interés del tema y por que se requiere de una referenciación al artículo de manera permanente.

La teledetección es una técnica de adquisión de datos a través del análisis y mapeo de los pixeles de imágenes tomadas por satélites que orbitan alrededor del planeta. Las imágenes MODIS-AQUA que se toman del oceáno produce una gran variedad de datos en varios rangos espectrales. El análisis del color (región visible) del océano produce información sobre la concentración de pigmentos de fitoplancton, de los sedimentos suspendidos, de la sustancia amarilla, conocida como Coloured Dissolved Organic Matter, CDOM, y de la clorofila-a 1]. El objetivo de este trabajo es determinar la concentración de la clorofila-a procedente de las imágenes MODIS en el mar peruano. Se analiza la variabilidad espacial y temporal de la concentración de clorofila-a a partir de imágenes MODIS usando el software ENVI e IDL en Windows, SEADAS en Linux y GIOVANNI independiente del sistema operativo. Los mapas de concentra-

\footnotetext{
*jrojasa@unmsm.edu.pe
} 
ción de clorofila-a promedio mensual de enero, febrero, marzo y abril del año 2006 han sido obtenidos del MODIS-AQUA usando el ENVI+IDL. En cada imagen mensual la variabilidad espacial de la clorofila-a en el mar peruano es diferente cerca a la costa y lejos de ella. En la costa norte del Perú $\left(0-5^{\circ} \mathrm{S}\right)$ la clorofila-a varía entre 0.05 a $0.5 \mathrm{gr} / \mathrm{cm}^{3}$ y se dispersa mas alejándose de la costa; en la costa central de Perú $\left(5^{\circ}-15^{\circ} \mathrm{S}\right)$ la clorofila-a varía entre 10 a $30 \mathrm{gr} / \mathrm{cm}^{3}$ y es más denso en la costa y disminuye lejos de la costa; en la costa sur de Perú $\left(15^{\circ}-20^{\circ} \mathrm{S}\right)$ la clorofila-a varía entre 3 a $5 \mathrm{gr} / \mathrm{cm}^{3}$ pero muy cerca a la costa. De enero a abril 2006 estos valores disminuyen lentamente por el cambio de estación. La aplicación web llamado GIOVANNI nos da resultados a través de series de tiempo del área de estudio sin descargar la gran cantidad de datos disponibles.

\section{Adquisión de los datos}

Los datos que se analizan en el presente trabajo han sido obtenidos de las siguientes fuentes.

\section{Los datos imágenes de satélite}

Los datos imágenes MODIS fueron obtenidos de Ocean Color Team [2] desde el 1 de enero al 30 de abril del 2006. La cantidad de imágenes trabajadas se distribuyen en 175 imágenes para enero, 174 imágenes para febrero, 188 imágenes para marzo y 170 imágenes para abril, en total son 707 imágenes trabajadas. Cada imagen de clorofila-a, LAC, tiene un tamaño de 82,608,128 bytes y para la imagen que tiene la latitud y longitud de cada píxel, MYD03, es de 30,113,792 bytes. El rango de valores de la clorofila es de $0.015-2.00$ hasta $64 \mathrm{mg} / \mathrm{m}^{3}$.

\section{Los datos in-situ}

Los datos de clorofila-a medidos en la Bahía de Independencia y Ancón por el equipo RIBEN [3] se encuentran ubicados en las coordenadas UTM (255731.897, $8698036.2)$ y $(372718.903,8413301.3)$ respectivamente. Estas corresponden a las mediciones realizadas a finales del mes de enero del 2006. La Figura 1 muestran sus valores para varias profundidades y en diferentes posiciones de medición. Estos datos han sido tomados muy cerca de la orilla, a menos de $5 \mathrm{~km}$.

\section{Procesamiento de las imágenes MODIS}

Para obtener el producto imagen concentración de clorofila- $a$ en el mar peruano a partir del sensor MO-
DIS a bordo del satélite AQUA se ha realizado los siguientes pasos: a) Las imágenes de nivel 2, level 2, son obtenidas de la pagina web Ocean Color [4 indicando el área de estudio de $0^{\circ}$ a $20^{\circ}$ latitud sur y de $90^{\circ}$ a $70^{\circ}$ longitud oeste y el tiempo de la imagen. b) Los datos imágenes de geolocalización se obtienen de la página web de LAADS [5]. c) La georeferenciación, el mosaico 2 y la reducción del área de estudio de las imágenes se realizaron con el software ENVI en Windows [6].

El mosaico de las imágenes de un solo día cubren las coordenadas de latitud de $0^{\circ}$ a $20^{\circ} \mathrm{S}$ y la longitud de $90^{\circ}$ a $70^{\circ} \mathrm{W}$ y tienen un tamaño de $2242 \times 2242$. La Figura 2 muestra el resultado de este procesamiento de imágenes. Giovanni es una aplicación web [7] desarrollado por la GES DISC, que proporciona una forma sencilla e intuitiva para visualizar, analizar y acceder a la gran cantidad de datos de teledetección de las ciencias de la Tierra sin tener que descargarlos. A partir de ello se han obtenido las Figuras 3 y 4 .
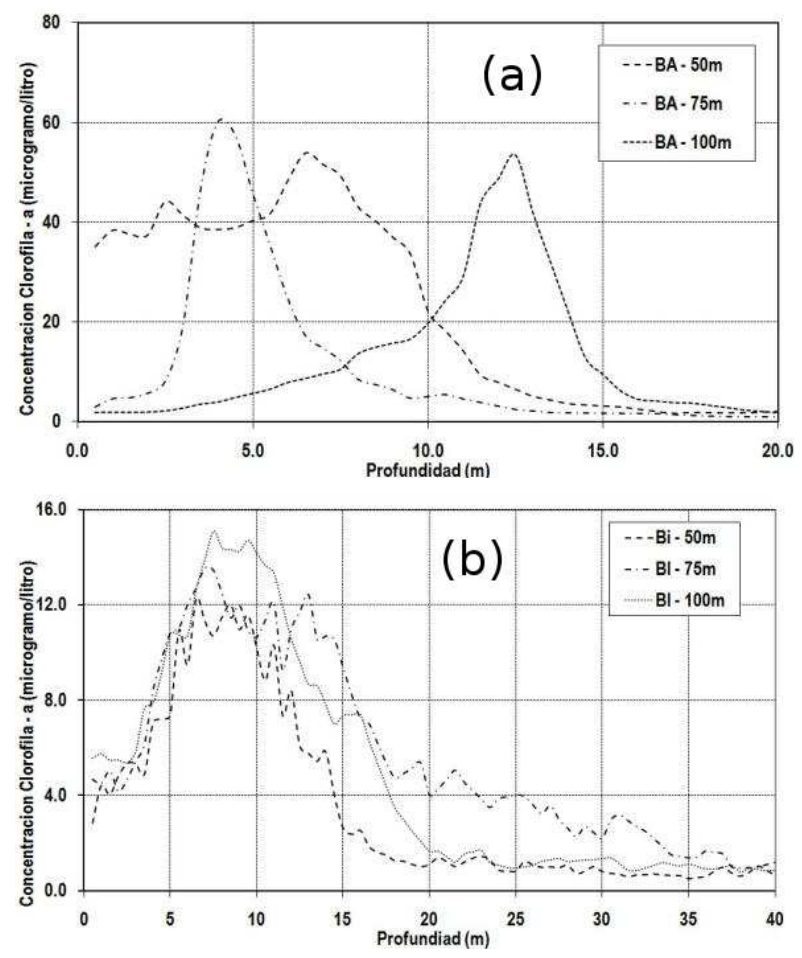

Figura 1: (a) Concentración de Clorofila-a en la Bahía de Ancón con coordenadas $-11.8^{\circ}$ y $-77.2^{\circ}[3]$. (b) Concentración de Clorofila-a en la Bahía de Independencia con coordenadas $-14.3^{\circ}$ y $-76.2^{\circ}[3]$. 


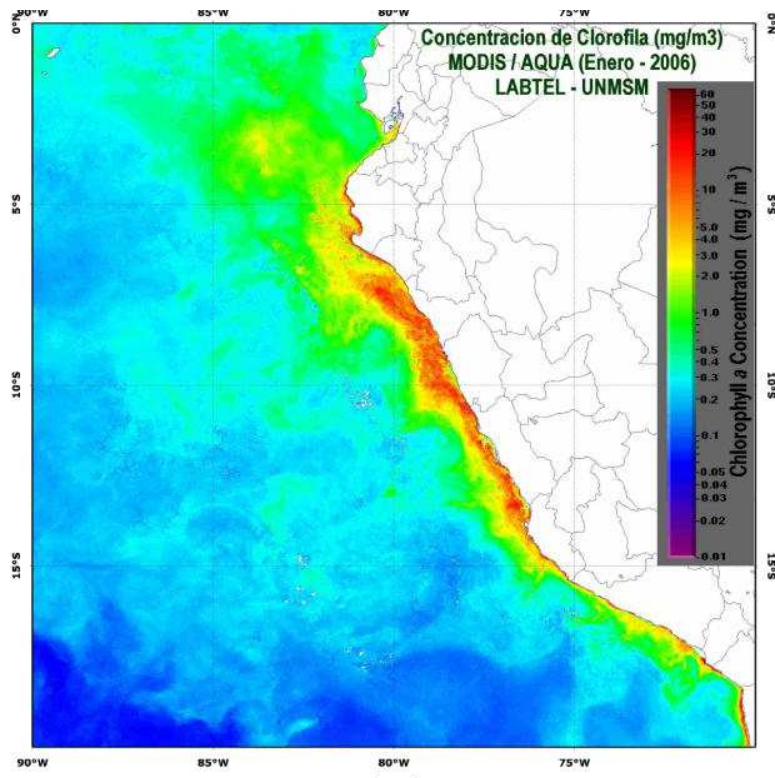

(a)

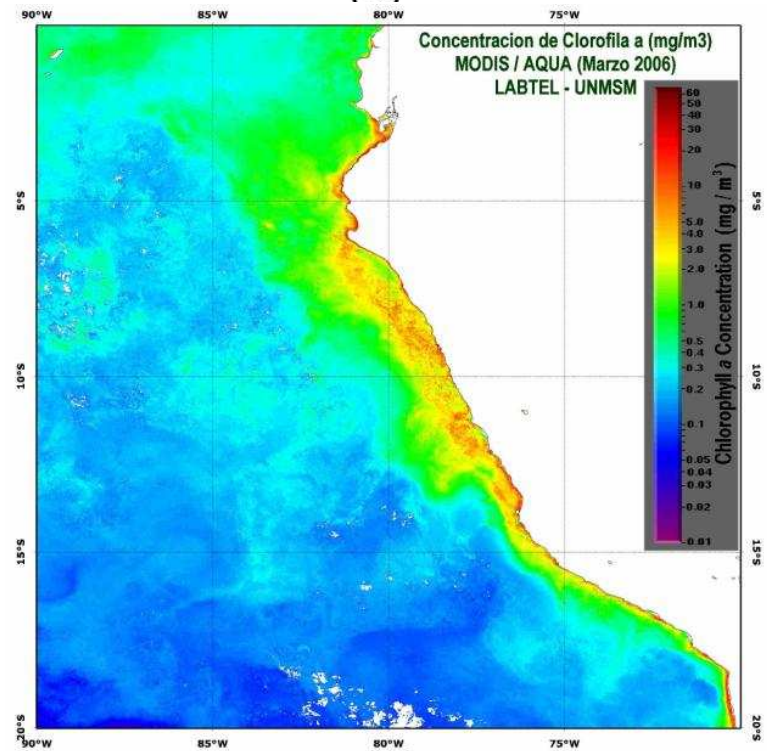

(c)

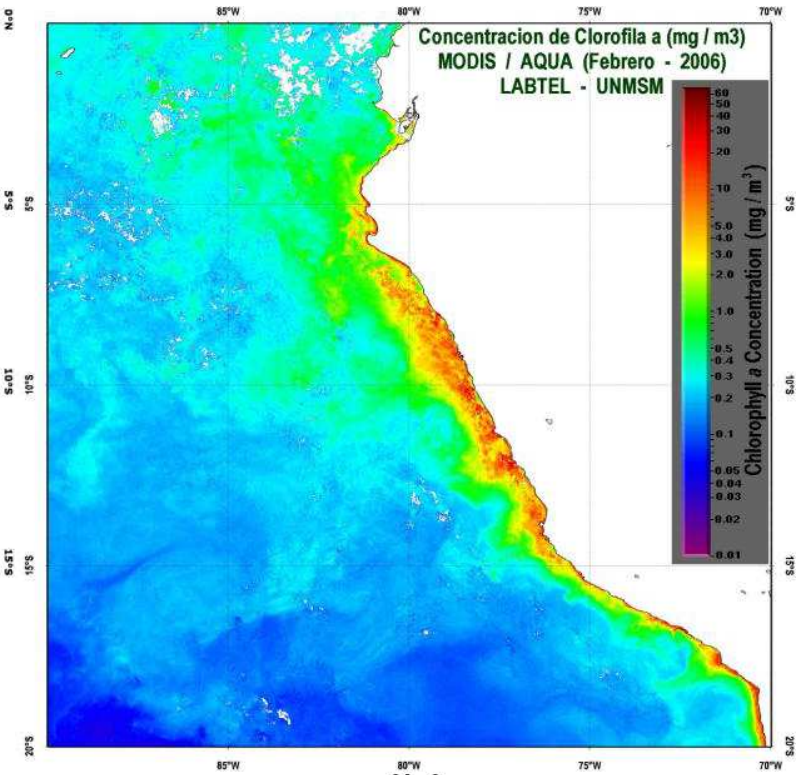

(b)

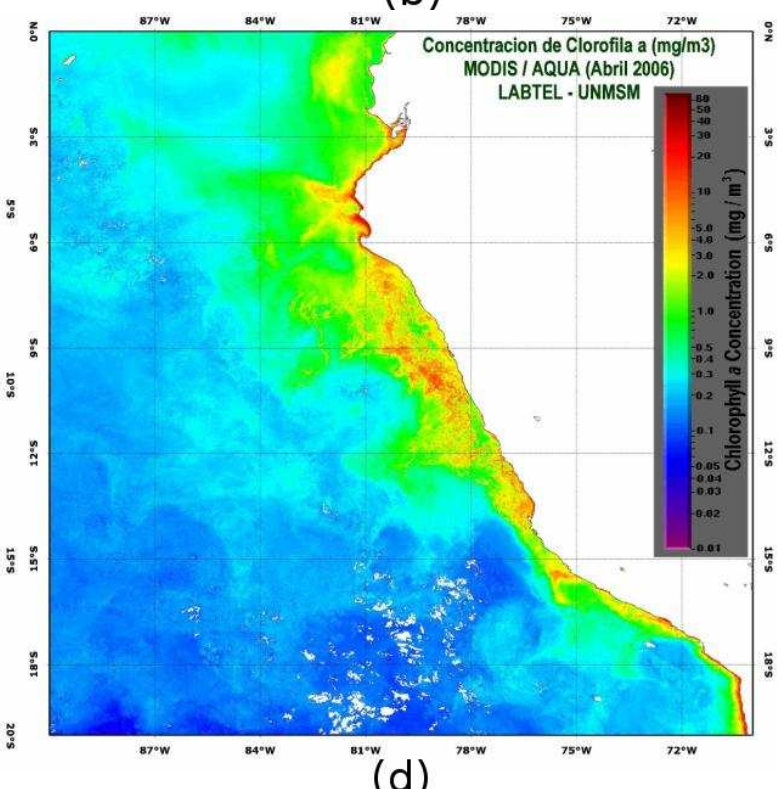

(d)

Figura 2: Concentración de clorofila-a de los meses de (a) enero, (b) febrero, (c) marzo y (d) abril del 2006 obtenido del sensor MODIS-AQUA. 

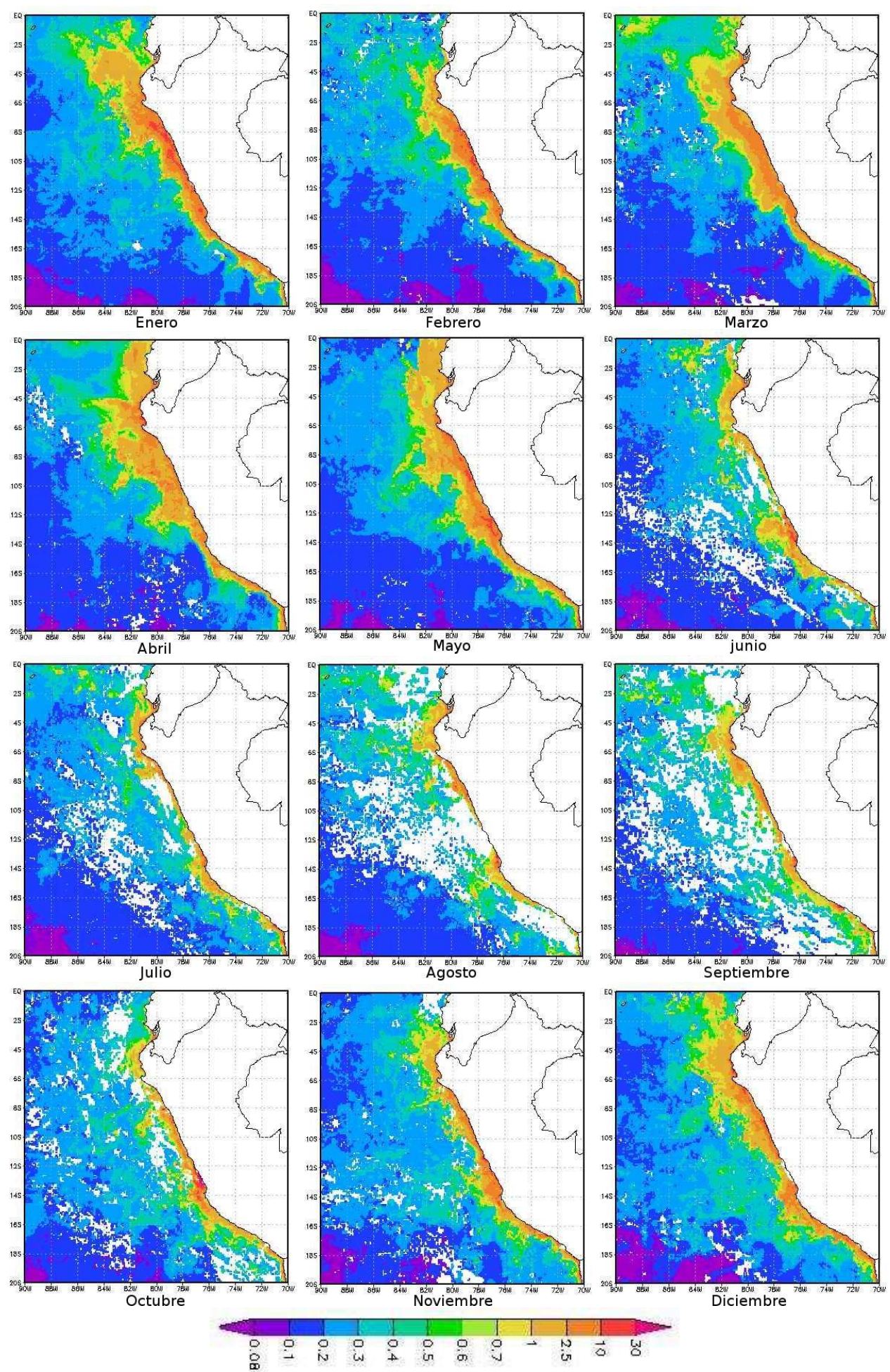

Figura 3: Concentración de la clorofila-a en $\mathrm{mg} / \mathrm{m}^{3}$ del litoral peruano comprendido entre $0^{\circ}-20^{\circ} \mathrm{S}$ y entre $90^{\circ}-70^{\circ} \mathrm{W}$ a partir de las imágenes MODIS-AQUA en el año 2006 de $9 \times 9$ km como resolución espacial. 


\section{Resultados y Discusión}

La variabilidad espacial y temporal de la clorofila-a de las imágenes MODIS-AQUA sobre el mar peruano, 0-20 $0^{\circ}$ y $90-70^{\circ} \mathrm{W}$, se muestran en la Figura 2 con una resolución espacial de $1 \times 1 \mathrm{~km}$, en el periodo comprendido de enero a abril del 2006. Se observa de la Figura 2 que los valores de la concentración de clorofila-a disminuyen mientras nos alejamos de la costa. Desde las costas de Chiclayo, $4^{\circ} \mathrm{S}$, a las de Paracas, $14^{\circ} \mathrm{S}$, se observan altos valores de clorofila-a, mayor que $10 \mu \mathrm{gr} / \mathrm{lt}$. En la costa norte desde Lambayeque a Tumbes los valores de clorofila-a son menores y tienen una mayor dispersión. Se debe de tener en cuenta que en el mar peruano confluyen cuatro corrientes oceanográficas, la corriente de Humboldt que recorre muy próximo a la costa posee una mayor concentración de clorofila-a y el efecto de la confluencia permite que la concentración de clorofila varíe constantemente, observándose en algunos meses una mayor concentración de clorofila-a en algunas zonas, así como también se observa una menor concentración de clorofila-a en otros meses en las mismas zonas.

En la Figura 3 se muestra la variabilidad espacial y temporal de la clorofila-a de las imágenes MODISAQUA sobre el mar peruano, $0^{\circ}-20^{\circ} \mathrm{S}$ y $90^{\circ}-70^{\circ} \mathrm{W}$, con una resolución espacial de $9 \times 9 \mathrm{~km}$, en el periodo de enero a diciembre del 2006. Se observa que en los meses de junio a noviembre del año 2006 la concentración de

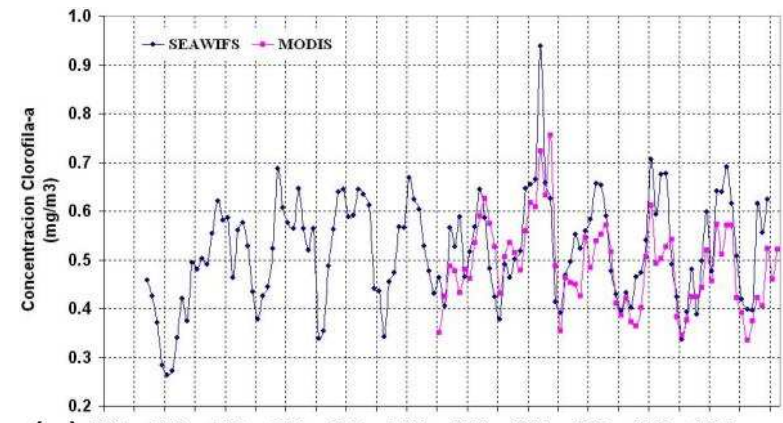

(a) $\begin{array}{lllllllllll}1997 & 1998 & 1999 & 2000 & 2001 & 2002 & 2003 & 2004 & 2005 & 2006 & 2007\end{array}$

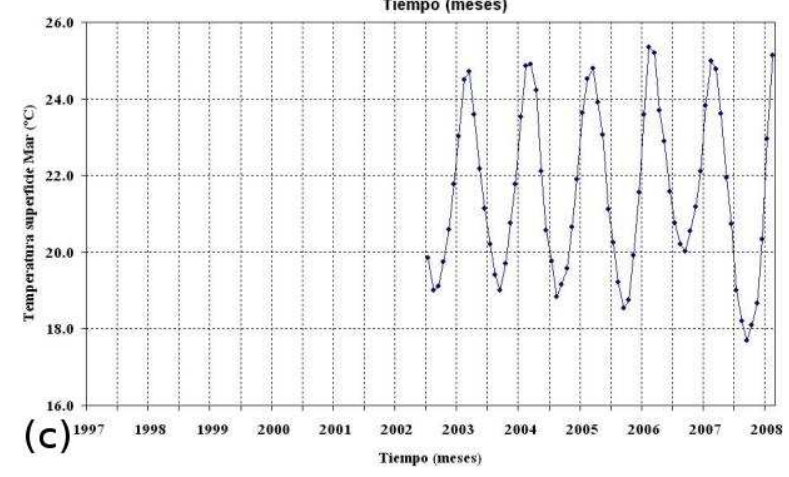

clorofila presenta valores mínimos y de diciembre a mayo presenta valores máximos. Esta variación estacional se muestra en la Figura 7 donde el promedio mensual del área de estudio muestra máximos en los meses de febrero a marzo y mínimos entre los meses de julio a agosto. Los valores de la concentración de clorofila-a del SEAWIFS es muy baja cuando se ha desarrollado un evento El Niño muy intenso como el Niño 1997-1998. Un gráfico de dispersión (ver Figura 8) entre la clorofilaa de SEAWIFS y MODIS da una correlación de 0.6 indicando que las mediciones con el SEAWIFS son ampliamente mas exactas. Las Figuras 9 y 10 muestran la variación anual de la temperatura de la superficie del mar de imágenes MODIS en el periodo 2002 a 2007. Las Figuras 11 y 12 muestra la evolución anual de la serie de tiempo del promedio mensual de la Concentración de Clorofila-a del Mar Peruano (0-20응 $\mathrm{S}$ y $\left.90-70^{\circ} \mathrm{W}\right)$ a partir de las imágenes MODIS (2002-2007) y SEAWIFS (1997-2007). La concentración de clorofila-a y la temperatura de la superficie del mar en el área de estudio está en fase, es decir, Los máximos de concentración de clorofila-a ocurre cuando son máximos la temperatura de la superficie del mar en esa área de estudio (Figura 13). La Figura 14 muestra la serie de tiempo de la anomalía del promedio mensual de la Concentración de Clorofila-a del Mar Peruano (0-20응 $\mathrm{S}$ y $\left.90-70^{\circ} \mathrm{W}\right)$ a partir de las imágenes SEAWIFS (1997-2007).
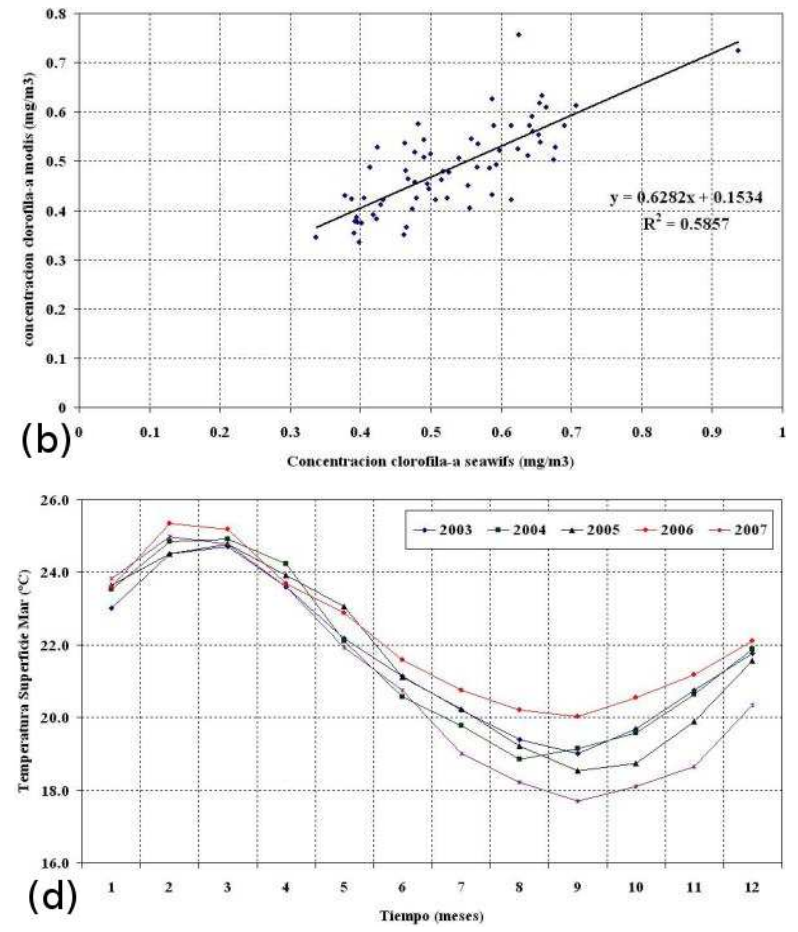

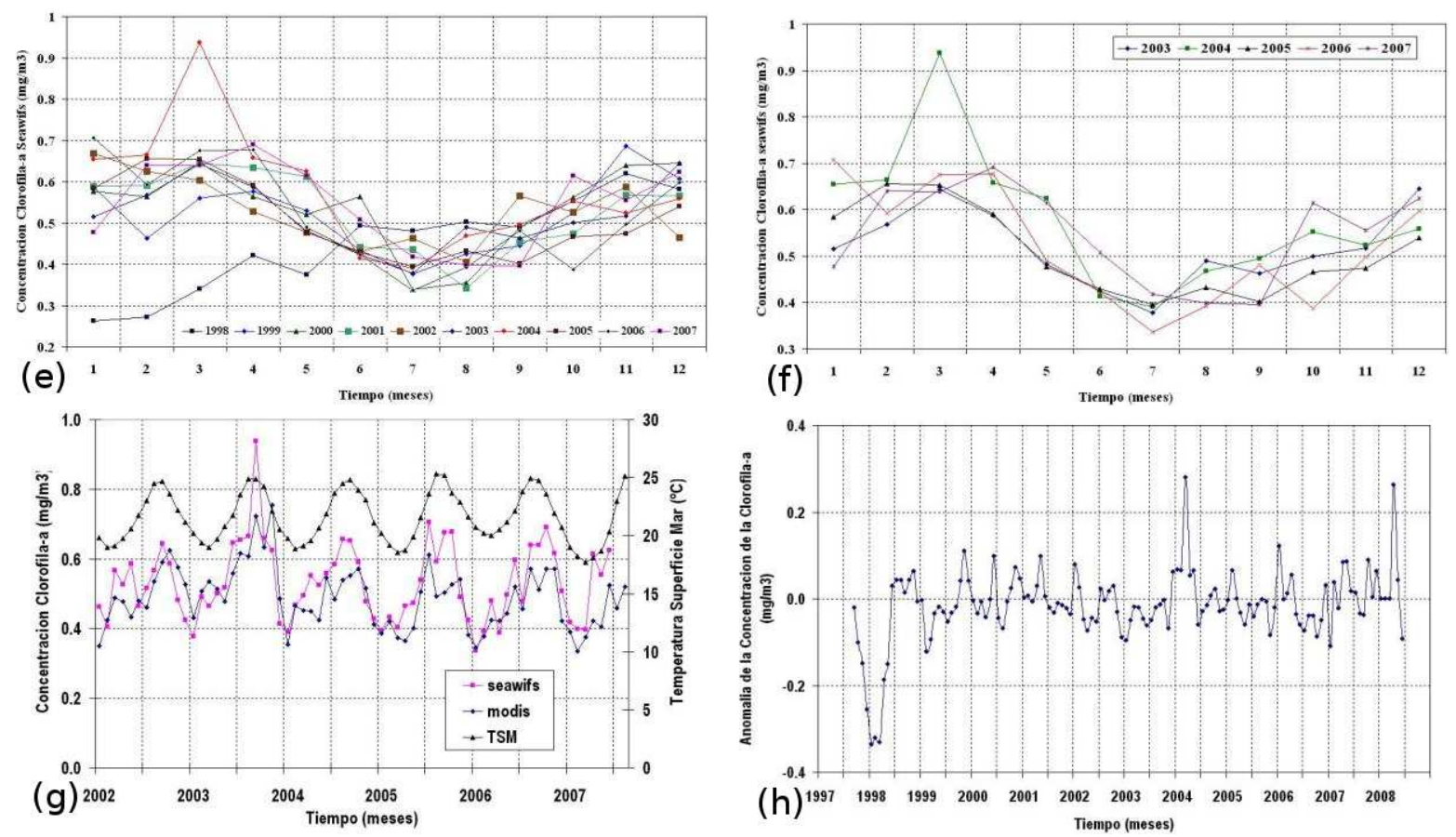

Figura 4: (a) Serie de tiempo promedio mensual de la concentración de la clorofila-a, $\mathrm{mg} / \mathrm{m}^{3}$, del litoral peruano, $0^{\circ}-20^{\circ} \mathrm{S}$ y $90^{\circ}-70^{\circ} \mathrm{W}$, a partir de las imágenes SEAWIFS en el periodo de 1997 a 2007 y MODIS en el periodo 2002 a 2008 . (b) Gráfico de la dispersión de la serie de tiempo promedio mensual de la concentración de la clorofila-a del litoral peruano, $0^{\circ}-20^{\circ} \mathrm{S}$ y $90^{\circ}-70^{\circ} \mathrm{W}$, a partir de las imágenes SEAWIFS y MODIS en el periodo 2002 a 2008. (c) Serie de tiempo promedio mensual de la temperatura de la superficie del mar, ${ }^{\circ} \mathrm{C}$, del litoral peruano, $0^{\circ}-20^{\circ} \mathrm{S}$ y $90^{\circ}-70^{\circ} \mathrm{W}$, a partir de las imágenes MODIS en el periodo comprendido desde el 2002 al 2008. (d) Evolución anual de la serie de tiempo promedio mensual de la temperatura de la superficie. (e) Evolución anual de la serie de tiempo del promedio mensual de la concentración de la clorofila-a del mar peruano, $0^{\circ}-20^{\circ} \mathrm{S}$ y $90^{\circ}-70^{\circ} \mathrm{W}$, a partir de las imágenes SEAWIFS en el periodo comprendido desde 1997 al 2007. (f) Evolución anual de la serie de tiempo del promedio mensual de la concentración de la clorofila-a del mar peruano, $0^{\circ}-20^{\circ} \mathrm{S}$ y $90^{\circ}-70^{\circ} \mathrm{W}$, a partir de las imágenes MODIS en el periodo de 2003 al 2007. (g) Serie de tiempo del promedio mensual de la concentración de clorofila-a del mar peruano, $0^{\circ}-20^{\circ} \mathrm{S}$ y $90^{\circ}-70^{\circ} \mathrm{W}$, a partir de las imágenes MODIS en el periodo 2002-2007 y de SEAWIFS en el periodo 2003-2007 y la temperatura de la superficie del mar peruano a partir de las imágenes MODIS en el periodo 2002-2007. (h) Serie de tiempo de la anomalía del promedio mensual de la concentración de la clorofila-a del mar peruano a partir de las imágenes SEAWIFS en el periodo 1997-2007.

\section{Conclusiones}

La concentración de clorofila-a del mar peruano a partir de las imágenes MODIS y SEAWIFS cambia en el tiempo y en el espacio debido a la interacción y presencia de las cuatro corrientes que bañan la costa peruana. La anomalía de la serie de tiempo de la clorofila-a adquirida de las imágenes SEAWIFS es mínima y negativa cuando está presente el evento El Niño 1997-1998. Las imágenes obtenidas durante los meses de enero, febrero, marzo y abril del 2006 obtenido del sensor MODISAQUA nos muestra altos valores de concentración de clorofila-a muy próximos a la costa. A medida que nos alejamos esta concentración va disminuyendo. La concentración de la clorofila-a del mar peruano obtenidas del SEAWIFS y del MODIS proporcionan una correlación de 0.6 indicando que las mediciones con el SEAWIFS son ampliamente más exactas. 


\section{Referencias}

[1] M. G. Quezada García, R. I. Paredes Peñafiel, F. Carrillo Gomero y J. Rojas Acuña, Rev. Inv. Fis. 14, 111402403 (2011).

[2] Ocean Color (2009); http://oceancolor.gsfc.nasa.gov/DOCS/MSL12 /master_prodlist.html/\#Rrs.

[3] J. Tarazona y C. Córdova, comunicación personal (2007).

[4] Ocean Color web (2008) http://oceancolor.gsfc.nasa.gov (2008).

[5] LAADS web- Level 1 and Atmosphere Archive and
Distribution System, (2008).

http://ladsweb.nascom.nasa.gov

[6] J. A. Rojas, Arnulfo Guillén Guevara, César Aguirre Céspedes, Juan Tarazona Barboza, César Córdova Castañeda, César Santisteban Alvarado, María Giuliana Quezada García y José Carlos Eche Llenque. Estudio de la Variabilidad espacial y Estacional de la Concentracion de la Clorofila-a en el Mar Peruano usando imágenes del sensor MODIS del satélite AQUA y su relación con el fenomeno El Niño en el Perú. Informe Técnico 2007, Instituto de Investigacion de Física.

[7] Giovanni (2008),

http://disc.sci.gsfc.nasa.gov/techlab/giovanni/ 